\title{
Introduction: \\ China - State, Public Policy and Society
}

\author{
EMILE KOK-KHENG YEOH AND LIANG-FOOK LYE \\ (GUEST EDITORS)
}

Over the last three and a half decades, the highly remarkable economic performance of the once low-income and inward-looking state of China has attracted increasing interest from academics and policymakers. According to official data, China superseded Germany to become the world's third largest economy in early 2008, ranked only after the United States and Japan. Based on a report published on China's National Bureau of Statistics website on 14 January 2009, the confirmed 2007 gross domestic product (GDP) of China at current prices amounted to 25.7 trillion yuan. ${ }^{1}$ While still short of a third of the USA's GDP, analysts then predicted China's GDP would overtake Japan's in three to four years, just as it overtook the United Kingdom and France in 2005 and Germany in 2008. Three years later, Yi Gang, the director of the State Administration of Foreign Exchange and the deputy governor of China's central bank, the People's Bank of China, announced on 30 July 2010 that China had already superseded Japan to become the world's second largest economy. ${ }^{2}$ Impressive as it is, beyond the stated intention of fostering modernization and marketization, China's reform and transformation have not been achieved in accord with an agreed and clearly established blueprint. Rather, it has been a result of policies and ideas formulated and tested as market-based reforms proceeded much in accordance with Deng Xiaoping's well-known gradualist dictum: 'crossing the river by groping the stones'. ${ }^{3}$ At the same time, as domestic economic reform and attendant social transformation were progressing at impressive speed, China has emerged as a regional and global power. China's transformed international profile has been one of the most pivotal changes underway in the contemporary world. It is a change that has also given rise to much debate over the weight to be given to domestic and external forces in explaining China's current world position.

One aspect of China's astounding economic development is the construction of a modern infrastructure and transportation system. In his article, 'China's Eagerness to Export its High-speed Rail Expertise 
to ASEAN Members', Yu Hong addresses this issue, focusing on the promotion of China's high-speed rail technology in foreign markets under its 'going-out' strategy.

On the political front, with the 18th National Congress of the Communist Party of China concluded on 15 November 2012 and the birth of a new Politburo Standing Committee, the Party thus completed its second orderly handover of power in more than six decades of its rule over this most populous country in the world, and today, the world's second largest economic entity. Nevertheless, also marking that year are various other poignant events that continue today that reflect strained State-civil society relations in this vast country. Among these, undoubtedly epitomizing the contemporary socio-political dilemmas of the People's Republic of China (PRC), is the proliferation of public protests mainly related to forced demolition and relocation, industrial pollution and official corruption, and related to this, the State response to civil rights-defending (weiquan) activism and its treatment of such activists as part of the wider dissident community. The continued unfolding of this systemic issue, indeed, has to be properly placed in the overall context of the problem of increasingly acute socio-economic inequality, including its ethno-regional dimension, which in many ways constitutes the epitome as well as the root of China's social ills resulting from its recent decades of continuous, astounding economic tour de force to the neglect of the modernization and democratization of its political structure and socio-political power configuration.

In their cynical take on the teleological hopes invested in the presumed continuous transition of the PRC from authoritarianism to liberal democracy, similar to what China's East Asian neighbours went through, especially South Korea and Taiwan, Dirlik and Prazniak (2012: 287-288) posed three questions:

First is the relationship to the legacies of the revolution of the Party and the people at large, including many dissidents, which is hardly the onedimensional relationship it is often assumed to be. Second is the relationship of questions of repression and dissent in the PRC to its structural context within global capitalism [...] finally, is there a case to be made that the PRC is better off exploring socialist alternatives in economy, society and politics than emulating models whose future is very much in question, in which case critique should be directed at holding the Party to its promise of socialism rather than its failures to live up to the examples of those who themselves are in retreat from democracy?

Dirlik and Prazniak's first two questions can be viewed in an integrated context, for State governance and civil societal response in today's 
China are intrinsically inseparable, while opponents of the Communist Party's continuing political monopoly have increasingly based their challenge upon the increasing socio-economic injustice under the Party's rule in the post-Mao era, and in facing the 'increasing legitimacy' of the Party's authoritarian grip following the last three decades of miraculous economic success of the 'China model'. This has resulted in a complex situation wherein, while the PRC 'presently suffers from severe economic and social inequality that may be sustained only by political repression',

It is frequently overlooked [...] that economic and social inequality are products of the very development policies for which the PRC is widely admired. The ironic consequence is that criticism directed at the PRC for its democratic deficit is more than compensated for by pressures to keep up a pattern and pace of development that gives priority to its functioning within the global system over the economic and political welfare of the population. Indeed, the 'China Model' has more than a few admirers who look to it with envy against the 'inefficiencies' thrown up by popular pursuit of justice in democratic societies. (Dirlik and Prazniak 2012: 287)

In his article, 'From 17th to 18th Party Congress: Implications for Intra-Party Democracy', Chen Gang examines how the new Xi Jinping (or $X i$ Jinping-Li Keqiang) administration strives to deal with the issue of regime legitimacy in an environment of a corrupted and inept officialdom, together with the challenge posed by intensified factional rivalry at various levels of the Party by attempting to adjust the authoritarian official-selection system by resorting to various 'intra-party democracy' initiatives such as informal polls among influential party officials and retirees.

On the economic front, even while the overall proportion of the Chinese population in poverty dropped significantly, from 30.7 per cent in 1978 to 3.4 per cent in 2000, according to government statistics, income inequality has been increasing, with the Gini coefficient reaching 0.415 in 1995 and continuing to rise (Chai et al. 2004: 2). At his first press conference in 2003 as China's premier, Wen Jiabao summarized the looming problems of his new post in a set of figures. These included China's labour force of 740 million vis-à-vis the Western advanced countries' total of just 430 million, and China's annual additional labour force of 10 million, xiagang ${ }^{4}$ and unemployed of about 14 million, and the rural-to-urban migrant labour of about 120 million - all giving rise to the huge employment pressure the country was facing (Liu 2010). In terms of poverty and stratification, Wen pointed out that there were 900 mil- 
lion peasants among the country's total population of 1.3 billion, with about 30 million still trapped in poverty. This latter figure was derived based on an annual income per capita of 625 yuan, which was in fact too low a poverty line. If the line were to be more accurately placed at 825 yuan, the rural poverty population would be about 900 million. In terms of interregional disparity, Wen pointed out that the GDP of the five or six provinces in eastern coastal China had exceeded 50 per cent of the national total GDP (Chai et al. 2004: 2).

Hence, while China's reforms have been successful in giving many people higher incomes and producing more goods and services, they also have led to increasingly acute inequality in income and wealth among the populace. From one of the most egalitarian societies in the 1970s, China has turned into one of the most unequal countries in the region and even among developing countries in general. Bert Hoffman of the World Bank noted in 2006 that China's Gini coefficient had risen from 0.25 in 1980 - equal to that of Germany - to about 0.45 , as the country became less equal than Russia or the USA. Yan (2010), on the other hand, gave a 'conservative' Gini estimate of 0.475 for the year 2007. In the 1980s, the richest 10 per cent of the people of China earned seven times the income of the poorest 10 per cent; today they earn more than 18 times as much. ${ }^{5}$ Or as another observer put it, 'Ever since the early years of reforms, the divide between the rich and the poor had been emerging, and it is now getting to the stage of ripping the entire society apart' (Zhou 2006: 286).

Similarly, Yan (2010) gave a high Gini coefficient for all China as early as 1994 at above 0.43 , which had risen to a 'conservative' estimate of 0.475 in 2007; this is of course a far cry from the Gini coefficient of below 0.3 (averages of 0.16 and 0.22 for urban and rural areas respectively) before the economic reforms. This alarmingly high Gini of 0.475 in 2007 represented a growth of 135 per cent from 1978, over a 29-year period in which GDP per capita (at constant prices) had grown by almost ten times over the pre-reform level with an average annual growth rate of 8.6 per cent. Yan (2010: 176-177) divided this growth of inequality into four phases:

1. The 'relatively egalitarian' (by international standard) period of 1978-1984 with Gini between 0.2 and 0.3 and little urban-rural disparity, while the rural economy developed immensely under the full force of reform;

2. The 'relatively justifiable' period of 1985-1992 with Gini hovering between 0.3 and 0.4 while the whole economy was expanding vi- 
brantly with the emphasis of reform shifting to the cities beginning in 1984. However, the accompanying inflation and expansion of the income gap had begun to overshoot people's psychological expectation threshold, resulting in rather serious social instability;

3. The worrying period of 1993-2000 of yearly increasing Gini index, with increasingly rapid reform and marketization pushing Gini over the internationally alarming line of 0.4 in 1993, and further over 0.43 in 1994, before the coefficient dropped back below 0.4 in 1995 and 1996. But it rose again with increasing urban-rural, employment, intercommunal and interstratum differentiation amidst the intensifying marketization and growth of the private-sector economy following the 15th National Congress of the Communist Party of China (CPC);

4. The high interest polarization period from 2001 to the present, wherein the globalization of China's growing economy and the wealth effect of the capital market have led to the continuous expansion of the income gap, with Gini reaching 0.475 in 2007, even by a 'conservative' estimate.

Yan (2010: 177-178) further pointed out that China's rural Gini has always been higher than the urban, implying that the intra-rural income disparity is fueling the expansion of the national income disparity, while the urban-rural income disparity is almost the main cause of the continuous expansion of the national income gap. In fact, the top 20 per cent urban income group's income is shown to be 5.5 times the income of the bottom 20 per cent urban income group whereas the top 20 per cent rural income group's income is 7.3 times the income of the bottom 20 per cent rural income group. ${ }^{6}$ Besides the urban-rural gap, such widening of income and wealth disparity is also manifest in various other aspects. Yan's analysis shows further that changes in the national Gini are positively related to changes in the urban-rural income ratio. Yan concludes that China's present Gini coefficient has reached a stage of too great a disparity and could be even higher if various informal incomes of the middle and upper strata are included in the calculation, even allowing for some scholars' view that China's Gini could be permitted to be higher, e.g. at 0.45 , a line that had almost been reached as early as 2001.

Loo-See Beh, in her article, 'China's Left-behind Children (Liu-shou-ertong): Development and Challenges for the Future', looks at an important social phenomenon that has resulted from the abovementioned widening socio-economic inequality and urban-rural disparity - the 'left-be- 
hind children' (liu-shou-er or liu-shou-er-tong). These are the children left behind in the villages or smaller townships when their parents move to larger urban areas as migrant workers. Beh highlights several challenges posed by this phenomenon to Chinese society and economy. It is endangering the next generation's development due to the severe mental and physical problems faced by these children during their growing stage, including poor performance in school, which affects their character and values as they become adults. It is endangering society's security as they have a higher risk of being involved as victims of accidents and crimes (e.g., sexual assaults on left-behind girls in rural areas account for the majority of reported assaults, according to the state news agency Xinhua) vis-à-vis children with both parents staying with them. They also tend to become criminals in later life because of the lack of supervision from parents to guide them on the proper way of life. This also endangers China's overall sustainable development and maintenance of the society's ethical and moral values. At 58 million, according to the All-China Women's Federation (ACWF) in 2008 based on the 2005 by-census, this means that one third or 28.29 per cent of the total population of rural children are 'left-behind children', a number that will inevitably increase in the future. Beh points out the importance of dealing with this problem before it becomes bigger and thus hinders the social and economic growth and development of China. Hence it is vital to analyse and find possible solutions relating to these problems, especially in terms of their education, health and social security.

As highlighted by Beh's paper in the case of the 'left-behind' children, Emile Kok-Kheng Yeoh and Kah-Mun Chu, in their article, 'Literacy and Education in Contemporary China: Daunting Challenges amidst Rapid Economic Development', recognize the significant relationship between education (and the eradication of illiteracy) and economic development as well as the effect of structural changes on the education system, and that literacy is the key to move China forward. The government of China, the country with the largest population and human resources among the developing countries in the world, according to Yeoh and $\mathrm{Chu}$, has always been aware of the importance of education in leading the nation to economic development, and over the years the government has been increasing the funding for public education. Yet, there are still poor families today who face problems in sending their children to school. While the cost of tuition and books has been increasing rapidly as richer families are sending their children for extra tuition, children in the rural areas are often more useful working in 
the fields than going to school. They become the direct victims of the new elitism, resulting in an increase in the number of illiterate youths as the dropout rate mirrors the rate of overall social dissatisfaction. In terms of State policy on education, the Chinese government launched the 'Resolution on Educational System Reform' in May 1985, and with this local governments were assigned full responsibility for primary education. As a result, schools with insufficient funds were unable to provide proper education to children, and consequently, the local governments shifted some of the burden of fees to the parents, which indirectly impeded poor families' sending their children to school. This was a problem especially where funding was unequal between rural and urban areas. Shortly thereafter, in 1986 the government doubled its investment in the education sector by introducing the 'Law of Nine-Year Compulsory Education' throughout China, level by level, according to the different areas' degree of socio-economic development. However, rural and urban areas are still being divided in terms of literacy rates, and gaps between these areas could widen even further.

The articles collected in this special issue thus show that despite the remarkable economic achievement in recent decades, the contemporary rise of China has brought various critical issues to the fore, which the country's government and the ruling Communist Party must urgently address. These are issues spanning the domains of political structure, foreign reach of the country's influence, socio-economic malaise and public policy in education to bridge the rural-urban gap, reduce inequality and maintain long-term social stability.

Earlier versions of the papers in this special issue were presented at the international conference 'From Hu-Wen to Xi-Li Administration: China's Leadership Transition and Its Domestic and International Implications', jointly organized by the Institute of China Studies, University of Malaya, and the East Asian Institute, National University of Singapore, on 12-13 September 2013, in Kuala Lumpur.

Emile Kok-Kheng Yeoh is Associate Professor at the Institute of China Studies, University of Malaya, Kuala Lumpur, Malaysia. He was the Director of the Institute of China Studies from 13 March 2008 to 1 January 2014 and is currently on sabbatical leave.

Liang-Fook Lye is Research Fellow and Assistant Director of the East Asian Institute, National University of Singapore. 


\section{NOTES}

1 Dongfang Ribao (Oriental Daily News, Malaysian daily), 16 January 2009. 'Yuan' is the largest denomination of China's currency 'renminbi' (RMB), equivalent to about US $\$ 0.146$ at the time referred to or today to about US\$0.161.

2 Dongfang Ribao (Oriental Daily News, Malaysian daily), 9 August 2010.

3 'Mo zhe shitou guo he.'

4 The term 'xiagang' refers to redundant workers mainly at state enterprises, without directly describing them as 'unemployed'. Still officially attached to their work units or enterprises, the xiagang workers continue to receive basic minimum subsidies for their living and medical expenses, and are encouraged to change jobs, probably through state-run job and re-employment centres, or go into small businesses.

5 Bert Hoffman, 'Access to Opportunity Eases Income Inequality', The Star (Malaysian daily), 21 January 2006.

6 Yan (2010: 179), based on data from China Statistical Yearbook 2008.

\section{REFERENCES}

Chai Jun, Chen Jing, Chen Kunling and Jiang Zhiqing 2004. 'Causes of Regional Poverty and Direction of Investment in Xinjiang, China'. Proceedings of the 16th Annual Conference of the Association for Chinese Economics Studies, Australia (ACESA), Brisbane, QLD, 19-20 July 2004. Available at: http://www.uq.edu.au/economics/acesa2004/ pro/Chai et al.pdf.

Dirlik, Arif, and Roxann Prazniak 2012. 'Social Justice, Democracy and the Politics of Development: The People's Republic of China in Global Perspective'. International Journal of China Studies 3 (3): 285-313.

Liu Yüeh-sheng 2010. Zhongguo Zui Ju Zhengyi de Ren: Wen Jiabao Quanzhuan [China's most controversial person: the full biography of Wen Jiabao]. Hong Kong: Mirror Books.

Yan Ye 2010. 'Shouru Fenpei Jiegou' [Structure of income distribution]. In Dangdai Zhongguo Shehui Jiegou [Social structure of contemporary China], edited by Lu Xueyi, pp. 173-214. Beijing: Shehuikexue Wenxian Chubanshe (Social Sciences Academic Press (China)).

Zhou, Linong 2006. China Business: Environment, Momentum, Strategies, Prospects. Singapore: Prentice Hall/Pearson. 